石油技術協会誌 第 67 巻 第 1 号 (平成14年 1 月)

JOURNAL OF THE JAPANESE ASSOCIATION FOR PETROLEUM TECHNOLOGY

VOL. 67, NO. 1 (Jan., 2002)

$\overline{\text { 論 } \quad \text { 文 }}$

\title{
地球化学からみた天然ガスの成因と熟成度*
}

\author{
早稲田 周**・岩野 裕継**・武田 信從**
}

(Received September 7, 2001 ; accepted January 11, 2002)

\section{Geochemical study on origin and maturity of natural gases}

\section{Amane Waseda, Hirotsugu Iwano and Nobuyori Takeda}

\begin{abstract}
Origin and maturity of natural gases are interpreted by the molecular and isotope data. Based on the carbon and helium isotope data, no indication of abiogenic gases has been found in commercial natural gases. Biogenic gases are classified into microbial and thermogenic gases by molecular and isotope compositions. However, secondary alteration (mixing, migration, microbial degradation, etc.) sometimes largely affects the compositions of natural gases. Microbial degradation especially alters both molecular and isotopic signatures for reservoired gases. Thus, although the prime order of isotopic and molecular fractionation in gases is due to genetic phenomena, secondary effects must be taken into account by putting together various pieces of information. If the secondary alteration is small, carbon isotope compositions of thermogenic hydrocarbons are largely controlled by the maturity. Berner and Faber (1996) developed isotope/ maturity models for methane, ethane and propane based on open-system dry pyrolysis experiments for Type II and III kerogens, and instantaneous kinetic models. The model for Type II kerogen was successfully applied to natural gases in Northeast Japan. The estimated maturity of gases in the Niigata Basin is generally higher than the Akita-Yamagata Basin. Besides the maturity estimation, the application of the model enables detection of microbial degradation, and mixing between microbial and thermogenic gases.
\end{abstract}

Key words: origin, maturity, natural gas, hydrocarbons, carbon isotope, hydrogen isotope, microbial, thermogenic, biodegradation, migration, maturity models

\section{1.はじめに}

原油が多くの複雑な化合物から成りその組成から起源 や熟成度に関して比較的多くの情報が得られるのに対 し, 天然ガスの組成は単純で, その分子組成から得られ る情報は少ない。しかし，1970年代に天然ガスの炭素安

* 平成13年 5 月 30 日，平成 13 年度石油技術協会春季講演会地 質・探鉱部門シンポジウム「新しい時代のガス資源」にて講 演 This paper was presented at the 2001 JAPT Geology and Exploration Symposium entitled "Natural gas:its origins and resource potential in the 21st century" held in Makuhari, Chiba, Japan, May 30, 2001.

**石油資源開発侏技術研究所 JAPEX Research Center, Japan Petroleum Exploration Co., Ltd.

Copyright (C) 2002, JAPT
定同位体組成が測定され始めて以来，その起源・熟成度 に関する研究は大きく発展した（Fuex, 1977 ; Stahl, 1979 ; Schoell, 1983など)。国内の天然ガスについて は, 坂田ら (1986), 早稲田・重川 (1988), Sakata et al. (1989), Sakata（1991）などが炭化水素組成・炭素 同位体組成データから，成因や熟成度についてま之めて いる。

近年では天然試料の分析データに加えて, 熱分解実験 や数学モデルによってガスの分子組成や同位体組成か ら, その成因 (起源) や熟成度を推定する研究が進展し ている。さらに, 微生物による二次的変質や移動による 分別作用についても新しい知見が蓄積されてきた。本稿 では，これらの知見を取り入れ，国内油・ガス田のデー 夕を例に, 分子組成・同位体組成からみた天然ガスの成 
因・熟成度に関して考察する。

また，ガスと油の中間的な存在としてコンデンセート の成因についても触れたい。ただし，本稿では可燃性天 然ガスの主成分である炭化水素の成因・熟成度の考察に 限定し, $\mathrm{CO}_{2}, \mathrm{~N}_{2}, \mathrm{H}_{2} \mathrm{~S}$ などの非炭化水素の成因につい ては言及しない。

\section{2. 試料と分析法}

国内坑井・基䃈試錐のテストガスおよび生産ガス 426 試料, 地表ガス徴試料34試料, 炭田ガス 5 試料, ガス八 イドレート分解ガス 2 試料について, 炭化水素組成, 炭 素同位体組成を分析した。一部の試料についてはメタン の水素同位体組成む分析した。これらデータの一部はす でに早稲田・重川（1988）が公表している。また, 国内 油・ガス田で採取した原油・コンデンセート 6 試料につ いて, API 比重，炭素同位体組成を分析した。

ガス組成の分析には島津 GC-7 A 型ガスクロマトグラ フ（TCD 検出器）を用いた。へリウムをキャリアガス とし, カラムにはモレキュラーシーブ $13 \mathrm{X}\left(\mathrm{O}_{2}, \mathrm{~N}_{2}, \mathrm{CH}_{4}\right.$ を分離）と $\mathrm{BMEE}\left(\mathrm{C}_{2} \mathrm{H}_{6} \sim \mathrm{C}_{6} \mathrm{H}_{14}\right.$ を分離）を使用した。

ガスの同位体組成の分析では, 真空ラインに直結した ガスクロマトグラフでメタン, エタン, プロパン, 二酸 化炭素を分離した。分離した成分を $850^{\circ} \mathrm{C}$ に加熱した酸 化銅炉に通し，二酸化炭素と水に変換した。水は亜鉛と とあにガラス管に封入し， $480^{\circ} \mathrm{C} て ゙$ 加熱し水素ガスに変 換した。二酸化炭素と水素ガスを安定同位体質量分析計 （VG アイソテック社製 SIRA Series III）に供し, 炭素 および水素同位体組成を測定した。原油・コンデンセー トの炭素同位体組成の分析では, 試料を酸化銅とともに 石英管に真空封入した後 $900^{\circ} \mathrm{C}$ で加熱し; 炭酸ガスと水 に変換した後，ガスの場合と同様の方法で測定した。炭 素同位体組成はPDB を，水素同位体組成は SMOW を 標準試料とした千分率偏差 $\left(\delta^{13} \mathrm{C} ; \%\right.$ ）で表示する。

\section{3. 天然ガスの成因}

\section{1 生物（有機）起源 vs. 非生物（無機）起源}

炭化水素ガスの成因としては, 第一に生物起源（biogenic）と非生物起源 (abiogenic) に分けられる。ガ ス組成からこれらを判別するには，炭素同位体組成と一 リウム同位体比が有効である。

地質時代の各種堆積有機物の炭素同位体組成の測定値 （-35〜-20\%。；Deines，1980） と熱分解実験結果 (Chung and Sackett, 1980 ; Rohrback et al., 1984な ぞ）.から，有機物の熱分解で生成したメタンの炭素同位 体組成は，-60〜 - 20\% 程度の範囲に入ると考えられ る。一方, 非生物起源と考えられる東太平洋海膨や
Zambales オフィオライト（フィリピン）中のメタン は，それぞれー18〜 - 15\% (Welhan and Craig, 1983)，－7\%。（Abrajano et al., 1988）という重い炭素 同位体組成を示している。

有機物の熱分解で生成したメタンおよびエタン以上の 炭化水素の炭素同位体組成は，炭素数が多いむのほど同 位体組成が重くなることが熱分解実験 (McCarty and Felbeck, 1986 ; Chung et al., 1988など) や, モデル 計算 (James, 1983 ; Sundberg and Bennett, 1983 ; Galimov, 1988など）で明らかになっている。一方，非 生物起源説として有名な地球深層ガス説 (Gold and Soter, 1980，1982）で想定されているように, 非生物 起源ではメタンの重合によってェタン以上の炭化水素が 生成すると推定される。この場合, メタンを使った火花 放電実験（Des Marais et al., 1981）で確かめられてい るように，熱分解とは逆に高分子の炭化水素ほど軽い同 位体組成を持つ。実際, アルカリ岩中の流体包有物 (Galimov, 1975）や隕石中の炭化水素（Yuen et al., 1984）の炭素同位体組成はこのようなトレンドをむって おり，無機的に生成したガスの特徴を示していると考え られる。

深部起源のガスのトレーサーとしてへリウム同位体比 がある。ヘリウムは, 大気, 地殼, マントルに由来す る。大気の ${ }^{3} \mathrm{He} /{ }^{4} \mathrm{He}$ は $1.4 \times 10^{-6}$ である。これを $\mathrm{Ra}$ と すると地殸は $0.04 \mathrm{Ra}$ 以下， マントルは $8 \mathrm{Ra}$ 以上であ る。したがって，およその目安として0.1Ra 以上の ${ }^{3} \mathrm{He} /{ }^{4} \mathrm{He}$ を示すガスにはマントル由来のへリウムが含ま れる可能性が高い。

以上をまとめると, 同位体組成からみた非生物起源ガ スの特徴は以下の 3 点である。

(1) メタン $\delta^{13} \mathrm{C}>-20 \%$

(2) メタン $\delta^{13} \mathrm{C}>$ エタン $\delta^{13} \mathrm{C}>$ プロパン $\delta^{13} \mathrm{C}$

(3) ${ }^{3} \mathrm{He} /{ }^{4} \mathrm{He}>0.1 \mathrm{Ra}$

$\delta{ }^{13} \mathrm{C}_{1}$ 值と $\mathrm{C}_{1} /\left(\mathrm{C}_{2}+\mathrm{C}_{3}\right)$ 比によるガスの起源分類図 (Bernard 図；Bernard，1978）に，国内天然ガスの データを示す（Fig. 1a)。これらのデータの中から， 起源, 熟成度, 地理的分布などの観点に基づいて選んだ 代表的な試料のデー夕を Table 1 と Fig. 1 b に示す。 国内油・ガス田の天然ガスで上記の(1)あるいは(2)に適合 するあのはない。このことは，これらのガスがすべて生 物起源であることを示唆する。一方，(3)に適合する天然 ガスは多い。新潟地域のグリーンタフ中のガスは，ほと んぞが 4Ra 以上である（Wakita et al., 1990)。Wakita and Sano (1983) やWakita et al. (1990) は, グリー ンタフ貯留層のガスについて，この高いヘリウム同位体 比を主な根拠とする無機成因説を提唱している。しか 


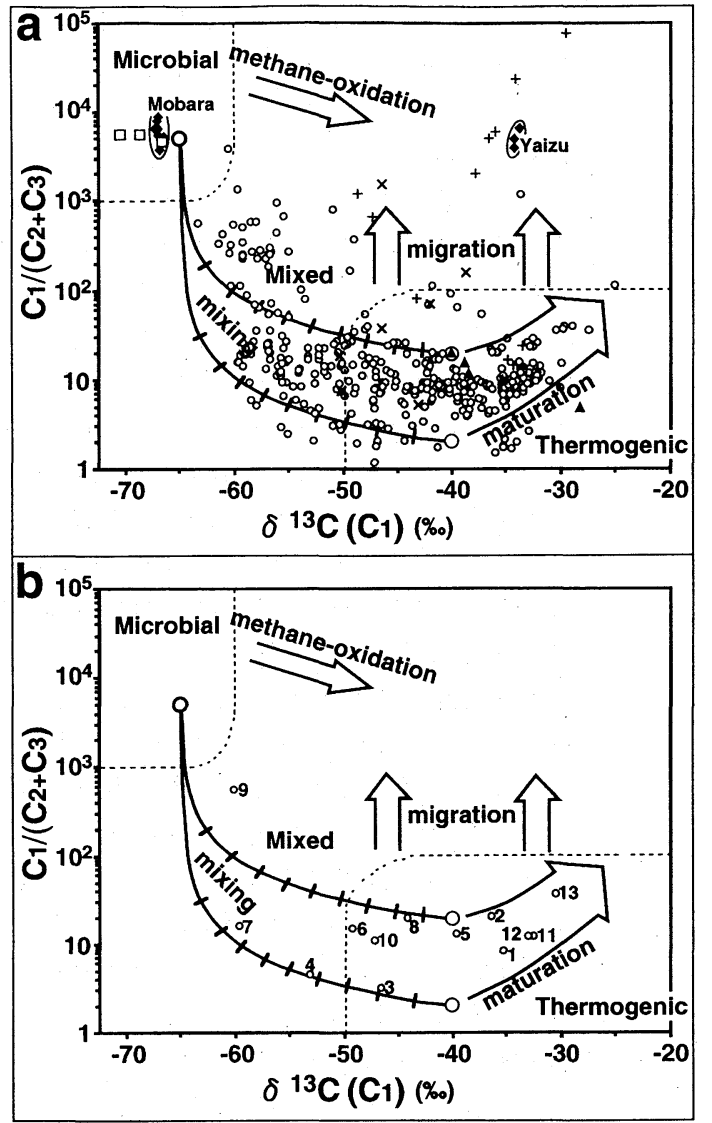

- oil/gas field test gas, production gas

$\Delta$ coal mine gas

口 gas hydrate dissociated gas (MITI Nankai Trough)

- natural gas of dissolved-in-water type

(Igari and Sakata, 1989)

$x$ gas seep (oil associated)

+ gas seep (non-associated)

O supposed end-member for microbial gas

o supposed end-member for thermogenic gas

Fig. 1 Genetic characterization of natural gases in Japan by methane carbon isotope compositions and methane/ (ethane+propane) ratios. a) all data ; b) selected data. Sample numbers refer to Table 1 .

し, Sakata et al. (1989), Sakata (1991) は, $\mathrm{CH}_{4} /{ }^{3} \mathrm{He}$ と ${ }^{3} \mathrm{He} /{ }^{4} \mathrm{He}$ の関係から，非生物起源のメタンを想定し なくてもグリーンタフ貯留層の高い ${ }^{3} \mathrm{He} /{ }^{4} \mathrm{He}$ を説明で きることを示し, ヘリウム同位体比のデータは炭化水素 の起源を判定する指標にはならないと指摘している。さ らに, 北ら（1999）は, $\mathrm{N}_{2} / \mathrm{Ar}$ 比と $\mathrm{He} / \mathrm{Ar}$ 比から，グ リーンタフ層準に無機起源のメタンが多量に含まれる可 能性がないことを示している。

\section{2 微生物起源 vs. 熱分解起源}

生物起源ガスは微生物起源ガスとケロジェンの熱分解

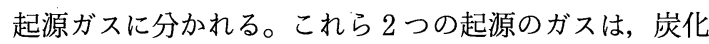
水素の組成比む同位体組成も異なる（Fig. 1)。 $\mathrm{C}_{1} /\left(\mathrm{C}_{2}\right.$ $+\mathrm{C}_{3}$ ) 比が高く（通常 1,000 以上), メタン炭素同位体組 成 $\left(\delta^{13} \mathrm{C}_{1}\right.$ 值) が軽い（通常－60\% 以下） ガスは, 一般 に微生物による有機物の分解で生成したガスとみなされ る。一方, $\mathrm{C}_{1} /\left(\mathrm{C}_{2}+\mathrm{C}_{3}\right)$ 比が低く（通常100以下）, $\delta^{13} \mathrm{C}_{1}$ 值が重い（通常－50\%0以上）ガスは，一般にケロジェン の熱分解起源ガスとみなされる。

なお，微生物起源ガス（microbial gas）のことを， 生物起源ガス（biogenic gas）あるいはバクテリアガス （bacterial gas）と呼ぶ場合も多い。しかし，生物起源 ガスの場合, 前項でのように非生物起源ガス（abiogenic gas）に対する用語として使う場合があるので, ここでは使用しない。また, バクテリアガスの場合, “メ タン生成菌は最近の遺伝子解析の結果から生物学的には 古細菌（Archaea）に分類され，真正細菌（バクテリ ア）とは異なることが明らかになっているため，本稿で は微生物起源ガスとする。

微生物起源ガスは比較的低温での微生物活動によるも のであるため, 一般に貯留層の深度は浅い。新潟や関東 の浅層に胚胎する水溶性ガスは代表的な微生物起源ガス である。ただし，同じょうな浅層の水溶性ガスでも，静 岡の焼津ガス田は $\delta{ }^{13} \mathrm{C}_{1}$ 值が重く (-34\%o; Igari and Sakata, 1989）熱分解起源を示唆する（Fig. 1)。これ は，深層で生成した熱分解起源ガスが上方移動で浅い地 層の水に溶存しているすのと推論され, $\mathrm{C}_{1} /\left(\mathrm{C}_{2}+\mathrm{C}_{3}\right)$ 比 が高いのは，移動時の分別と解釈できる（Igari and Sakata, 1989)。移動の効果については, 後述する。海 洋のメタンハイドレートに含まれるメタンも多くは微生 物起源である（早稲田・内田，1998）。基礎試錐「南海 トラフ」で採取されたメタンハイドレートの分解ガスも 微生物起源ガスである（Fig. 1)。

微生物によるメタン生成には以下の 2 種類の経路があ る。

二酸化炭素の還元 : $\mathrm{CO}_{2}+4 \mathrm{H}_{2} \rightarrow \mathrm{CH}_{4}+2 \mathrm{H}_{2} \mathrm{O}$

酢酸の発酵: $\mathrm{CH}_{3}-\mathrm{COO}^{-}+\mathrm{H}^{+} \rightarrow \mathrm{CH}_{4}+\mathrm{CO}_{2}$

酢酸発酵は淡水の堆積物や沼地, 二酸化炭素還元は海 洋堆積物における，それぞれ主要なメタン生成経路であ る（Whiticar et al., 1986)。 Schoell (1988) は堆積物 の温度，有機物の基質および年代がどちらの経路が優勢 となるかを決める主要な因子と推定している。

これら 2 種類の微生物起源ガスおよび熱分解起源ガス を判別するには, メタンの水素同位体組成と炭素同位体 組成が有効である。二酸化炭素還元で生成したメタンの 


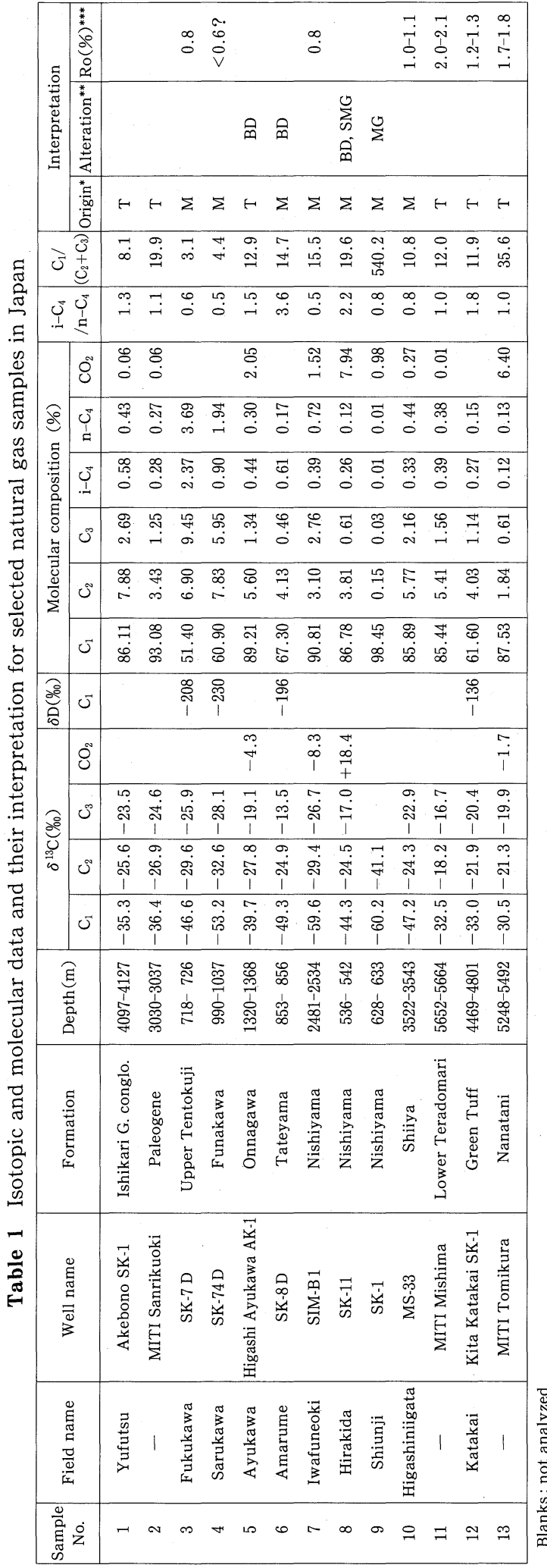

水素同位体組成 $\left(\delta \mathrm{D}_{1}\right)$ は $-250 \sim-150 \%$ ，酰 酸発酵で生成したメタンの水素同位体組成は一 $400 \sim-250 \%$ といわれている (Schoell, 1988)。Fig. 2 にメタンの水素同位体組成と炭 素同位体組成によるガスの起源分類図を示す。 ODP Leg 164においてブレークリッジで採取さ れたガス八イドレート分解ガス中のメタンは二 酸化炭素還元で生成したと推定される（Matsumoto et al., 2000)。基礎試錐「南海トラフ」 で採取されたメタンハイドレートの分解ガスも ブレークリッジとほぼ同じ組成を示し，二酸化 炭素還元で生成したメタンであることを示す。 一方，カナダのマッケンジーデルタで採取され たメタンハイドレートの分解ガスは熱分解起源 である (Uchida et al., 1999)。

国内坑井の産出テストガスおよび生産ガス は，Fig. 1 上でほとんどが熱分解起源ガスあ るいは，熱分解起源ガスと微生物起源ガスの混 合ガスを示す領域にプロットされる。Fig. 1 には，ある組成の熱分解起源ガスと微生物起源 ガスが混合した場合，混合比によってどのよう に組成が変化するかを示す。微生物起源ガスの 端成分としては $\mathrm{C}_{1} /\left(\mathrm{C}_{2}+\mathrm{C}_{3}\right)$ 比 $5,000, \quad \delta^{13} \mathrm{C}_{1}$ 值－65\%。仮定する。熱分解起源ガスの端成分 としては $\delta^{13} \mathrm{C}_{1}$ 值を $-40 \%$ とし， $\mathrm{C}_{1} /\left(\mathrm{C}_{2}+\mathrm{C}_{3}\right)$ 比は実際のデー夕のばらつきから幅を持たせ, 2 あるいは 20 と仮定した。このばらつきの原因 の一部は, 採取時の圧力の違いによると推定さ れる。坑井のテストガスや生産ガスでは, 同じ 貯留層からのガスであ採取場所・採取方法に よって採取時の圧力が変化する。圧力の違いは $\delta{ }^{13} \mathrm{C}$ 值には影響しないが, $\mathrm{C}_{1} /\left(\mathrm{C}_{2}+\mathrm{C}_{3}\right)$ 比に は影響する。

混合ガスの領域に入るものの中で $\mathrm{C}_{1} /\left(\mathrm{C}_{2}+\right.$ $\mathrm{C}_{3}$ ) 比が数十以下のものは, 2 本の混合ライン の間に入る試料が多い。しかし，それ以上では 2 本の混合ラインで挟まれる領域よりも $\delta^{13} \mathrm{C}_{1}$ 值が重い側にずれるものが多い（Fig. 1a)。こ れらの試料は比較的浅部の眝留層から採取され たものが多く, 移動によって $\mathrm{C}_{1} /\left(\mathrm{C}_{2}+\mathrm{C}_{3}\right)$ 比 が変化したものと推定される。移動による炭化 水素組成の変化の影響は，地表のガス徵に大き く表れている (Fig. 1a)。特に油と共存しない ガスには $\delta{ }^{13} \mathrm{C}_{1}$ 值が重いにもかかわらず， $\mathrm{C}_{1} /$ $\left(\mathrm{C}_{2}+\mathrm{C}_{3}\right)$ 比が一般的な微生物起源ガスと同程 度に高いガスが多く，これらは地下深部で生成 


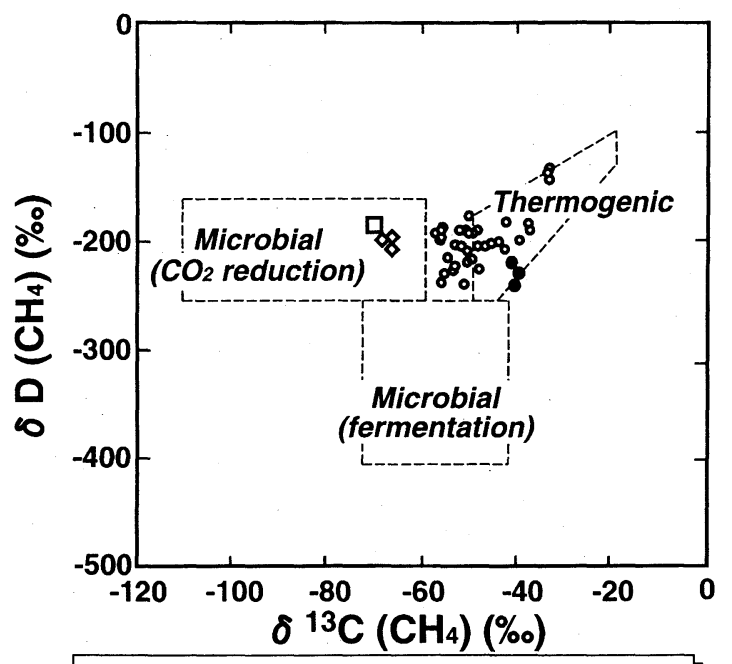

Oil/gas field in Japan

- test gas, production gas

Gas hydrate dissociated gas

- Mallik 2L-38, Mackenzie Delta (Uchida et al., 1999)

$\checkmark$ ODP Leg 164, Blake Ridge (Matsumoto et al., 2000)

口MITI Nankai Trough

Fig. 2 Genetic characterization of natural gases by carbon and hydrogen isotope compositions of methane.

した熱分解起源ガスが地表へ移動する間に炭化水素組成 が変化したものと推定される。

Fuex（1980）が，移動によってガス組成はドライに なる（エタン以上のガスの割合が減少する）が炭素同位 体組成は変化しないことを室内実験から結論して以来, 移動による炭素同位体組成の変化はないと考えられてき た。Igari and Sakata（1988）は，国内天然ガスの分析 データから, 移動によって同位体組成は変化せず, 組成 のみがドライに変化していることを示している。しか し, 最近, 貯留層からのリークなど, 拡散によってガス が移動する場合，メタン炭素同位体組成が軽くなるとの 指摘がある (Prinzhofer and Pernaton, 1997 ; Prinzhofer et al., 2000)。熱分解起源ガスと微生物起源ガス が混合した場合，その混合比に応じて Bernard 図上で データは曲線状に分布するのに対して, 拡散の場合, Bernard 図上でのデータの分布は直線状になる（Prinzhofer and Pernation, 1997)。国内油・ガス田のガスの 場合は, 新潟市周辺のように浅部に微生物起源の水溶性 ガスが存在することああり，前述したように熱分解起源 ガスと微生物起源ガスの混合によって主に同位体組成は 変化していると考えられる。しかし, 今後は拡散による 同位体組成の変化あありうることを考慮してデータを解
釈する必要がある。

国内油・ガス田のガスは $\delta^{13} \mathrm{C}_{1}$ 值がー $35 \%$ より重い領 域では， $\delta{ }^{13} \mathrm{C}_{1}$ 值が重くなるにつれて $\mathrm{C}_{1} /\left(\mathrm{C}_{2}+\mathrm{C}_{3}\right)$ 比が 高くなる傾向がある。これは熟成の進行によるガス組成 の変化を示していると考えられる。この点については， 熱分解起源ガスの熟成度として，4 章で詳細に考察す る。

\section{3 ケロジェンタイプとガスの生成}

熱分解起源ガスは, 起源となった有機物のケロジェン タイプによってガスの生成量が異なる。ケロジェンは夕 イプごとに $\mathrm{H} / \mathrm{C}$ 比が大きく異なり，この違いが生成す るガス油比に影響する。ケロジェン中の炭素が油とガス に変換される割合の理論的な計算值（Hunt, 1995）は Table 2 に示すと打りで，ケロジェンタイプごとに油へ の変換率が大きく異なる。タイプIIIケロジェンではタイ プII ケジェンの $1 / 2$ 以下しか油に変換されない。ガス への変換率は夕イプIIIケロジェンが最も高いが，油ほよ゙ には差が大きくない。結果的に，ガス油比はケロジェン タイプごとに大きく異なる。ガス油比の違いは根源岩か ら貯留層への炭化水素の移動時期に影響する。タイプII ケロジェンでは, 油の生成量が多いため, 比較的早期に 油が移動できるが，タイプIIIケロジェンでは油の生成量 が少なく, 特に石炭は油の吸着能力が高いため, ガスが 十分に生成してからガスに溶解する形で移動する可能性 が高い。

タイプI / II ケロジェンとタイプIII ケロジェンでは, 生成するガスの組成も異なる。タイプの違いによるガス の相対生成量を Fig. 3 に示す。一般に陸源有機物（夕 イプIIIケロジェン）からのガスは, 海洋藻類有機物（夕 イプII ケジェン）に較べてェタン以上の重質炭化水素 ガスの生成が少なく，二酸化炭素や窒素の生成量が多 い。ただし, ガス組成は熟成度や 2 次的な分別, 溶解 ・ 沈澱（特に二酸化炭素）に影響されるため，ガス組成の みから起源ケロジェンのタイプを推定することは難し い。Table 1 に示す試料では, 共存する油のバイオマー

Table 2 Estimatiom of the theoretical maximum TOC convertible to the carbon of hydrocarbons (after Hunt (1995))

\begin{tabular}{|l|c|c|c|}
\hline Kerogen type & I & II & III \\
H/C initial & 1.45 & 1.25 & 0.85 \\
H/C final & 0.3 & 0.3 & 0.3 \\
\hline & \multicolumn{3}{|c|}{ maximum \% of TOC converted } \\
\hline to C in oil and gas \\
\hline Oil & 58 & 42 & 18 \\
Tas & 4.5 & 6.2 & 7.2 \\
Total & 62.5 & 48.2 & 25.2 \\
\hline
\end{tabular}




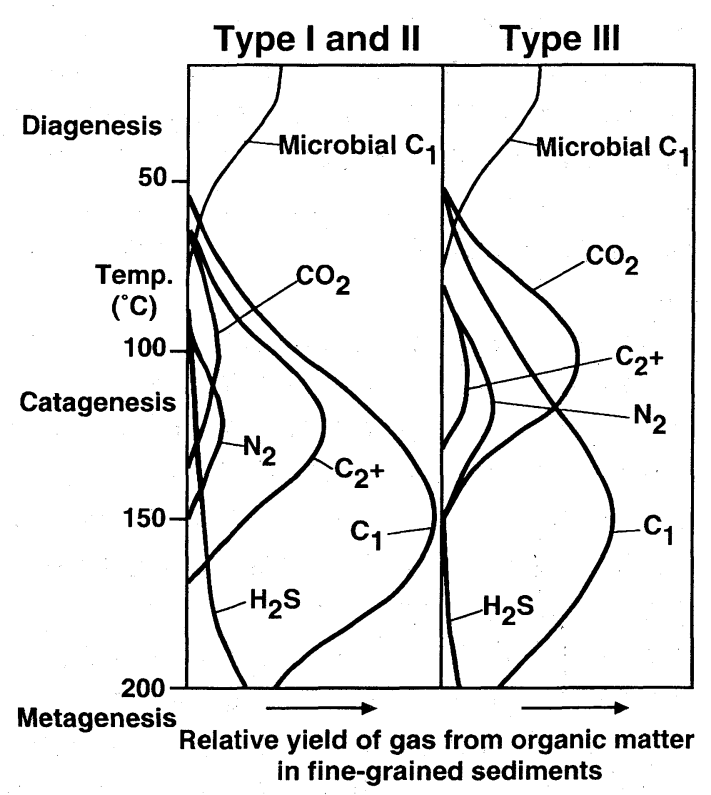

Fig. 3 Relative yield of gas from Type I/II and Type III kerogens, modified after Hunt (1995).

カーなどから勇払油ガス田と基礎試錐「三陸沖」の 2 試 料（試料番号 1，2）は陸源有機物起源, それ以外の秋 田〜新潟の試料は海洋藻類起源と推定される。しかし, ガス組成には起源有機物タイプから推定される上記のよ うな組成の特徴は認められない。

\section{4 微生物分解}

油の微生物分解と同様に，ガスも微生物分解を受け る。油と同様にイソアルカンよりあノルマルアルカンが 選択的に分解されるため, 高い $\mathrm{i}-\mathrm{C}_{4} / \mathrm{n}-\mathrm{C}_{4}$ 比を示す。油 では軽質な成分が選択的に分解されるが，ガスでは, 分 解を受けやすい成分は必ずしも一定ではない。Whiticar and Faber（1986）は，世界各地の海底または湖底 の表層堆積物中のガスのデータから, 微生物がエタン以 上の炭化水素ガスよりあメタンを選択的に分解している ことを示した。この場合, 残りのメタンの $\delta^{13} \mathrm{C}$ 值は重 くなり $\mathrm{C}_{1} /\left(\mathrm{C}_{2}+\mathrm{C}_{3}\right)$ 比は低下するため, Bernard 図上 では Fig. 1 に示す methane-oxidation の矢印のように 組成が変化する。静岡の焼津ガス田は, 移動によって炭 化水素組成が変化した熱分解起源ガスとして解釈できる ことを 3.2 節で示したが， もう1つの説明として，微生 物起源ガスの微生物による酸化分解が考えられる。しか し，焼津ガス田の場合は，微生物分解が起こった場合に 生成する二酸化炭素が検出されないことから，この可能 性は低い（Igari and Sakata, 1989)。メキシコ湾の海底 に分布するガスハイドレート中のガスは，周囲の湧出ガ
スに較べて低い $\mathrm{C}_{1} /\left(\mathrm{C}_{2}+\mathrm{C}_{3}\right)$ 比と重い $\delta{ }^{13} \mathrm{C}_{1}$ 值を持ち, 微生物によるメタンの酸化分解が起こっていることを示 す (Sassen et al., 1998)。

一方, James and Burns（1984）はオーストラリア北 西大陸棚 Exmouth Plateau の深度 $2,651 \mathrm{~m}$ で採取され たガスが異常に重いプロパン $\delta^{13} \mathrm{C}(-3.67 \% 0)$ を示すこ とから，プロパンが選択的に微生物に分解されたと考え ている。国内では余目油田, 平木田ガス田, 鮎川油ガス 田で採取されたガスも同様に異常に重いプロパン $\delta^{13} \mathrm{C}$ を示しており（Table 1)，プロパンの選択的分解が考 えられる。

さらに, Clayton et al. (1997) は北海で, Pallasser （2000）はオーストラリア北西大陸棚と Gippsland と Otway Basin で採取されたガスについてエタンが選択 的に分解されている場合があることを示している。この ように，ガスの場合，選択的に分解される成分は必ずし あ一定でない。メタンの選択的分解とエタン・プロパン の選択的分解では $\mathrm{C}_{1} /\left(\mathrm{C}_{2}+\mathrm{C}_{3}\right)$ 比の変化が逆なので注 意が必要である。

以上のように, 地下にはメタン生成菌, メタン酸化 菌, さらに，エタンやプロパンを選択的に酸化分解する 菌も存在する。最近, 油の微生物による酸化分解とメ夕 ン生成が同時に起こっている可能性が指摘されている。 一般に油の微生物分解は, 酸素を溶存した地表水の貯留 層への浸入によるものと解釈されるが, Connan et al. （1997）は娧気的環境での微生物分解が広く起こってい ると主張している。嫌気的環境ではメタン生成菌が活動 できる。嫌気的環境下の貯留層内で油が微生物分解を受 けて生成した二酸化炭素から，メ夕ン生成菌によりメ夕 ン生成が起こっているとしている。このようなガスは, 堆積初期の有機物分解による微生物起源ガスと区別し て, 二次的微生物起源ガス（Scott et al., 1994）と呼ば れる。その特徵は, ガス組成がドライで,メタン炭素同 位体組成が比較的軽く，二酸化炭素を多く含み，その炭 素同位体組成が 0 ～$+20 \%$ 程度の重い值を示すことで ある (Dimitrakopoulos and Muehlenbachs, 1987; Pallasser, 2000)。国内では, 平木田ガス田の試料が約 $8 \%$ 二酸化炭素を含み, $\delta^{13} \mathrm{C}\left(\mathrm{CO}_{2}\right)$ が+ $18.4 \%$ と重い ことから (Table 1), この現象が起こっていると推定 される。

\section{5 コンデンセートの成因}

コンデンセートは高圧の貯留層でガスとして存在する が，地表では液状の軽質油である（通常 API >55; Hunt, 1995)。コンデンセートの主な成因として以下の 3 種類が挙げられる。

(1) 高熟成におけるケロジェン/油の熱分解 
（2）垂直移動時の気液分離

(3) 脱アスファルト化による重質分の分離

(1)のコンデンセートは, 熟成の進行に伴う油とガスの 中間生成物として考えることができる。この場合, 通 常, 油層よりあ深部にコンデンセート層が形成される。 油とコンデンセートが共通の根源岩から生成した場合, コンデンセートの $\delta^{13} \mathrm{C}$ 值は油よりも重くなる。

(2)のコンデンセートは，油が上方へ移動する過程で圧 力変化によって気液分離が起こり, 気相が選択的に移動 するために形成される。この現象は “separationmigration”（Silverman, 1965）あるいは “evaporative fractionation" (Thompson, 1987) と呼ばれる。 (1)とは逆に浅部にコンデンセート, 深部に油層が形成さ れ，コンデンセートの $\delta^{13} \mathrm{C}$ 值は, 油よりあ軽くなる。

(3)のコンデンセートは, 油層に大量のガスが流入する ことによって重質分（アスファルテン）が沈澱し, 残り の油が軽質化することで形成される (deasphalting)。 重質分の沈澱物は有機溶媒に不溶の有機物として眝留層 ビチューメンと呼ばれ，元の油との間に炭素同位体組成 の分別はほとんどない (Rogers et al., 1974)。したがっ て,この過程で生成したコンデンセートの $\delta^{13} \mathrm{C}$ 值む元 の油とほぼ同じになると推定される。

以上の 3 種類の成因における深度および炭素同位体組 成と API 比重の関係を Fig. 4 に示す。 Table 3, Fig. 5 には国内油・ガス田における原油・コンデンセートの データを示す。このうち，(1)の成因によると考えられる のは新潟の片貝ガス田のコンデンセートである。(2)にあ たるのは秋田の鮎川油ガス田のコンデンセートである。 北海道の勇払油ガス田のコンデンセートは(3)の成因と推 定される。このようにコンデンセートの成因を明らかに することは, 石油システムを解明する手がかりとして重 要である。

\section{4. 天然ガスの熟成度}

\section{1 熟成度亡炭素同位体組成}

天然ガス中の炭化水素の炭素同位体組成は, ガス生成

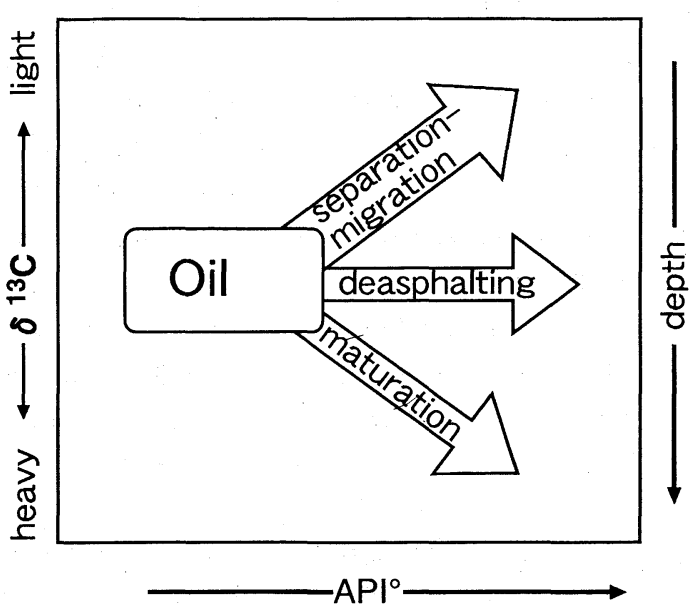

Fig. 4 Relationships among depth, API gravity and carbon isotope compositons for three formation processes of condensates.

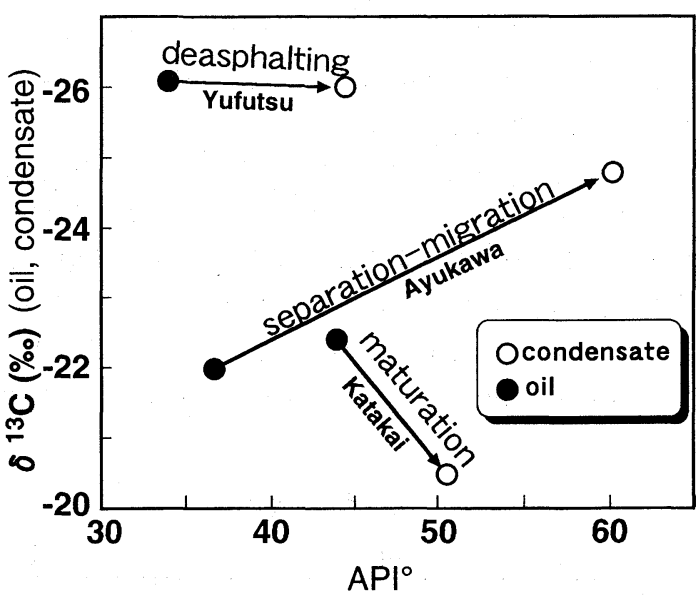

Fig. 5 Relationships between carbon isotope compositions and API gravity for three oil-condensate pairs in Japan, representing different origins of condensates.

Table 3 Carbon isotope composition atd API gravity data for oil-condensate pairs from three fields in Japan

\begin{tabular}{|l|l|l|l|l|l|l|}
\hline Field name & \multicolumn{1}{|c|}{ Well name } & \multicolumn{2}{|c|}{ oil/condensate Formation } & Depth $(\mathrm{m})$ & $\mathrm{API}^{\circ}$ & $\delta^{13} \mathrm{C}(\% 0)$ \\
\hline \multirow{2}{*}{ Katakai } & SK-22 & oil & Lower Teradomari & $3079-3103$ & 44.0 & -22.4 \\
& SK-18 & condensate & Green Tuff & $4395-4710$ & 50.6 & -20.5 \\
Ayukawa & Kita Ayukawa AK-1 & oil & Onnagawa & $1704-1727$ & 36.8 & -22.0 \\
& Kita Ayukawa AK-1 & condensate & Onnagawa & $1448-1494$ & 60.2 & -24.8 \\
Yufutsu & Akebono SK-1 & oil & Ishikari G. coal & $3595-3611$ & 34.0 & -26.1 \\
& Akebono SK-1 & condensate & Granite & $4298-4453$ & 44.6 & -26.0 \\
\hline
\end{tabular}


時の熟成度を反映する。しかし，その他にも起源ケロ ジェンの炭素同位体組成, ケロジェンタイプ, 微生物起 源ガスの混入, 微生物分解などの影響を受ける可能性が ある。これらの生成後の二次的要因が小さければ，同じ ケロジェンから生成したガスについては，定性的にはそ の炭素同位体組成が重いほど相対的に高い熟成度で生成 したと判断できる。

天然ガスの炭素同位体組成が測定され始めた初期の頃 から，同位体組成データをもとに熟成度を推定する試み がなされた。Stahl（1979）は，ドイッ，米国など限ら れた地域の限られたデータから，ケロジェンタイプに よってビトリナイト反射率（Ro）とメタン炭素同位体 組成の間の関係は大きく異なることを示し, 海成根源岩 （タイプII）と陸成根源岩（タイプIII）からのガスにお ける Ro と $\delta^{13} \mathrm{C}_{1}$ 值の関係を推定した（Fig. 6)。しか し, タイプの違い以外にも起源ケロジェンの炭素同位体 組成の違いが $\delta{ }^{13} \mathrm{C}_{1}$ 值に影響するのは明らかであり，こ れを考慮していないことには問題がある。実際，国内の ガスデータをこの図に当てはめた場合, タイプII起源と 考えられる片貝ガス田のガスは異常に高い熟成度を示 す。さらに，多イプIII起源の勇払油ガス田のガスは異常 に低い熟成度になってしまう（Fig.6）。

1980年代に入ると経験則に加えて熱力学, 反応速度論 に基づく理論計算によって，メタンとエタンなど異なる 炭素数の炭化水素間の炭素同位体組成の差から生成温度 （熟成度）を推定する方法が提案された（James, 1983 ； Sundberg and Bennett, 1983 ; Chung et al., 1988 ; Roony et al., 1995など)。この場合，起源ケロジェンの

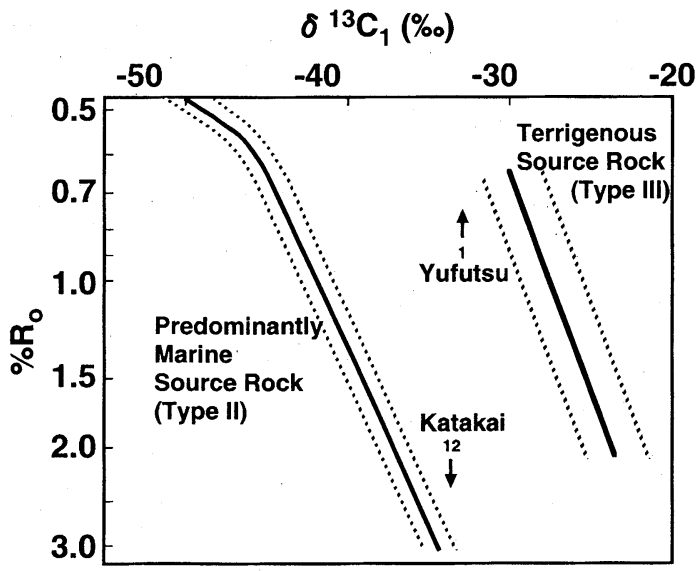

Fig. 6 Relationships between methane carbon isotope compositions and vitrinite reflectance, modified from Stahl (1977). Sample numbers refer to Table 1 .
タイプや同位体組成の違いは熟成度の推定に影響しな い。Fig. 7 に James（1983）による炭化水素の炭素同 位体組成と熟成度の関係を示す。熟成度は James （1983）では TAI（Thermal Alteration Index）および LOM（Level of Organic Metamorphism）で表されて いたが, LOM とRo の関係（Hood et al., 1975）を基 にRoに変換して示した。この図に申川油田（試料番号 4 ), 福川油田（同 3 ）, 片貝ガス田（同12）, 基礎試錐 「三陸沖」(同 2 )，勇払油ガス田（同 1 ）のデータを示 す (Fig. 7)。エタンとプロパンの炭素同位体組成の差 を図中の変化直線に合わせて示した。この図から，生成 時の Ro は申川・福川が $0.7 \%$ 前後, 片貝・基礎試錐 「三陸沖」・勇払は1.0～1.4\%程度と評価される。メタン 炭素同位体組成については，いずれの試料もこの図から 予測される值よりも軽い方向にずれる。このずれについ ては, 申川・福川の場合は, 微生物起源ガスの混合で解 釈できるものの, その他の 3 試料については微生物起源 ガスの混合は考えにくく，モデルに問題がある可能性が 高い。これら 3 試料についてメタンとエタンの炭素同位 体組成を図中の変化直線に合わせた場合は，1\%以下の Ro と評価される。

Chung et al. (1988) は, 根源ケロジェンから同時に 生成した場合に，速度論に基づく同位体分別の考察から 導かれる炭素数と炭素同位体組成の関係を示す図 (Natural Gas Plot) を提案している。この図は微生物 起源ガスの混合や異なる根源岩からのガスの混合などの 評価に有効である。Igari（1999）はこれを使い，新潟，

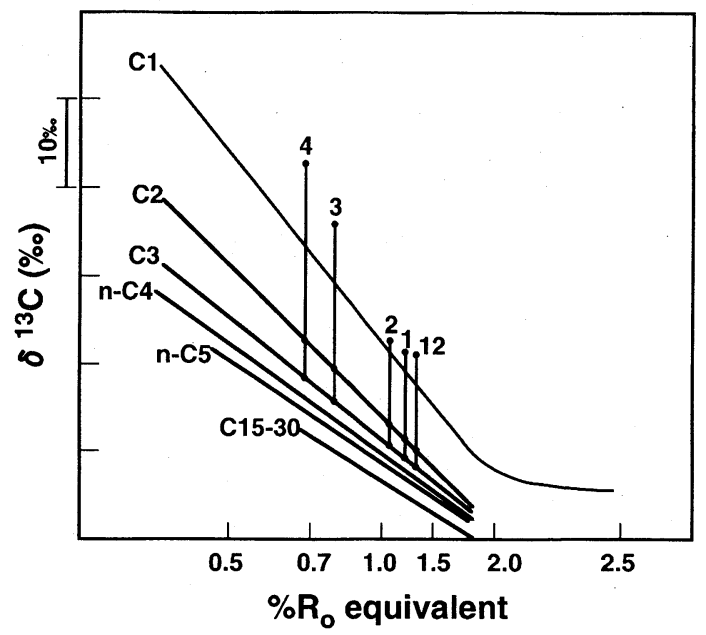

Fig. 7 Relationships between carbon isotope compositions of different carbon numbers and vitrinite reflectance, modified from James (1983). Sample numbers refer to Table 1 . 
秋田のガスにおける微生物起源ガスの混合や根源ケロ ジェンの炭素同位体組成を推定している。

近年では, 天然データの解釈に加えてケロジェンの熱 分解実験および数值計算から，さまざまなモデルが提案 されており, 熟成度の定量的な評価の試みがなされてい る (Berner et al., 1995 ; Berner and Faber, 1996 ; Lorant et al., 1998 ; Tang et al., 2000など)。その結果, ケロジェンタイプ（Berner et al., 1995）, 開放系か閉鎖 系か (Lorant et al., 1998), 生成は瞬間的か長期の累積 か (Tang et al., 2000), などによって同位体組成, 炭 化水素組成, 熟成度の相互関係が異なることが明らかに なっている。

Berner et al. (1995), Berner and Faber (1996) は, タイプII およびタイプIII ケロジェンの非含水開放系での 熱分解実験のデータと速度論に基づく同位体分別の計算 から，それぞれのタイプごとにビトリナイト反射率とメ タン・エタン・プロパンの同位体組成の関係をモデル化 している。

実験データを統計的なカーブフィッティングで近似す ることによって, タイプIのケロジェンからのガスにつ いては, Ro $=0.5 \sim 2.5 \%$ 範囲で以下の炭素同位体組 成と熟成度の関係式を導いている。

$$
\begin{aligned}
\delta^{13} \mathrm{C}_{1}= & -4.0613 \mathrm{Ro}^{5}+34.924 \mathrm{Ro}^{4}-113 \mathrm{Ro}^{3} \\
& +171.26 \mathrm{Ro}^{2}-111.86 \mathrm{Ro}+9.265+\delta^{13} \mathrm{Ci} \\
\delta^{13} \mathrm{C}_{2}= & 7.4991 \mathrm{Ro}^{6}-81.906 \mathrm{Ro}^{5}+354.73 \mathrm{Ro}^{4} \\
& -772.76 \mathrm{Ro}^{3}+881.75 \mathrm{Ro}^{2}-482.97 \mathrm{Ro} \\
& +90.083+\delta^{13} \mathrm{Ci} \\
\delta^{13} \mathrm{C}_{3}= & -2.0174 \mathrm{Ro}^{6}-8.294 \mathrm{Ro}^{5}+14.76 \mathrm{Ro}^{4} \\
& -126.87 \mathrm{Ro}^{3}+236.04 \mathrm{Ro}^{2}-165.11 \mathrm{Ro} \\
& +33.875+\delta^{13} \mathrm{Ci}
\end{aligned}
$$

ここで $\mathrm{Ci}$ はガスの起源有機物の炭素同位体組成である。 次節ではこれらの式を使って，タイプIケロジェン起 源と考えられる秋田・山形, 新潟堆積盆のガスに応用す る。

なお, Berner and Faber (1996) はタイプIIIについ ても同様の検討を行い, Ro $=1.5 \sim 2.5 \%$ の範囲で炭素 同位体組成と熟成度の関係式を導いている。しかし, $\mathrm{Ro}<1.5 \%$ では実験の $\delta^{13} \mathrm{C}_{1}$ と計算值が一致しないた め, $\mathrm{Ro}=1.5 \sim 2.5 \%$ のデー夕を外挿しており, 夕イプ IIIについての Berner and Faber (1996) のモデルは信 頼性が低い。

\section{2 国内天然ガスの熟成度}

Berner and Faber (1996) のモデルに秋田〜新潟地 域（タイプII ケロジェン起源）を適用する。起源ケロ ジェンの炭素同位体組成は, 本地域原油における芳香族 炭化水素の炭素同位体組成の平均値から推定する。その
理由は, 油の主な起源化合物が長鎖のアルキルと考えら れるのに対して, ガスの起源化合物は芳香族環に付いて いる短鎖アルキルが多いと推定されるからである。早稲 田（1993）のデータによれば, 新潟地域の原油 9 個の芳 香族炭化水素の炭素同位体組成は $-22.36 \%$ （標準偏差 0.65), 秋田・山形地域の原油16個の芳香族炭化水素の 炭素同位体組成は-22.29\%（標準偏差0.38）である。 これらのデータから起源有機物の炭素同位体組成を一 $22.3 \%$ と仮定した。

秋田・山形および新潟地域におけるメタンおよびエ夕 ン炭素同位体組成と, Berner and Faber (1996) の夕 イプIIモデルから推定される熟成ライン（同位体組成 とビトリナイト反射率の関係）を Fig. 8 に示す。ほと んどの試料が熟成ラインよりも $\delta^{13} \mathrm{C}_{1}$ が軽い側にプロッ トされる。これは微生物起源のメタンが混合している試 料が多いことを示す。新潟と秋田・山形ではデー夕の分 布範囲が異なり, 新潟地域の方が $\delta^{13} \mathrm{C}_{2}$ が重い。これは 全体的に新潟地域のガスの方が熟成度が高いことを反映 していると推定される。この結果は, 秋田・山形地域に 較べて新潟地域の原油の熟成度が全体的に高い (Sakata et al., 1988 ; 早稲田, 1992) ことと調和的であ る。

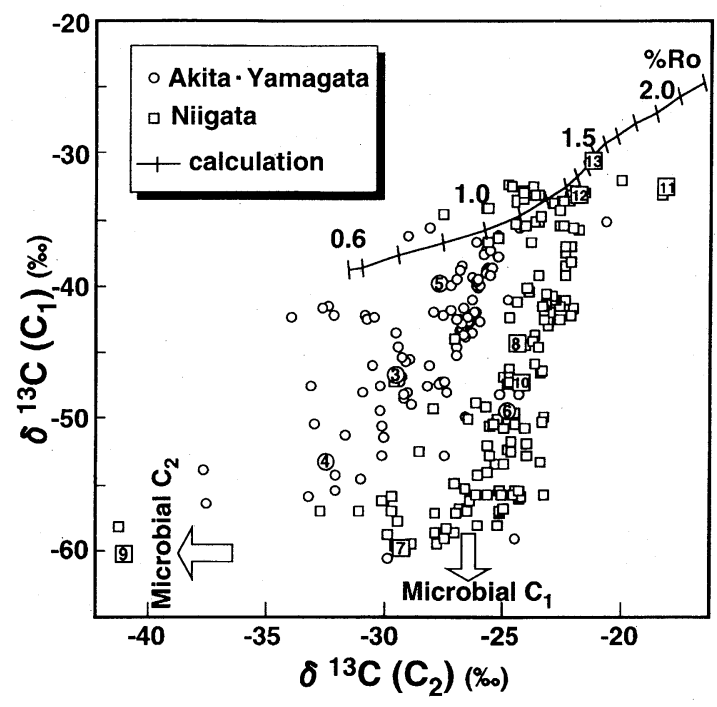

Fig. 8 Relationships between methane and ethane carbon isotope compositions of natural gases in Japan. The vitirnite reflectance/isotope composition line is obtained by calculations using formulas from Berner and Faber (1996), supposing kerogen is Type II and the carbon isotope composition is $-22.3 \%$. Sample numbers refer to Table 1. 
両地域と屯 $\delta^{13} \mathrm{C}_{1}$ と $\delta^{13} \mathrm{C}_{2}$ には相関関係が認められる。 この原因の 1 つは微生物起源のメタンの混合量が多い試 料ほど, 貯留層の深度が浅く, 熱分解起源ガスの熟成度 あ低い傾向があるためと推定される。あう1つの要因と して, 微生物起源のメタンとと屯に微生物起源で $\delta^{13} \mathrm{C}_{2}$ の軽いエタンが混合している可能性が挙げられる。微生 物起源の天然ガスはほとんどメタンからなるが，エタン 以上の炭化水素す微量生成する (Oremland et al., 1988)。その炭素同位体組成はメ夕ン同様軽く, Mattavelli et al. (1992) は北イタリアのガズ田でー58\%0の炭 素同位体組成を示すエタンを, Waseda and Didyk （1995）はチリ沖の堆積物中に- $69.9 \%$ の炭素同位体組 成を示すエタンを報告している。国内試料についても紫 雲寺ガス田の試料は $-41.1 \%$ という異常に軽い $\delta^{13} \mathrm{C}_{2}$ を 示しており (Table 1, Fig. 8), 微生物起源エタンの混 合が推定される。

秋田・山形および新渴地域におけるエタンおよびプロ パン炭素同位体組成と, Berner and Faber (1996) の モデルから推定される熟成ラインの関係を Fig. 9 に示 す。この図ではプロパン炭素同位体組成が熟成ラインょ りあ重い側に離れてプロットされる試料が秋田・山形地

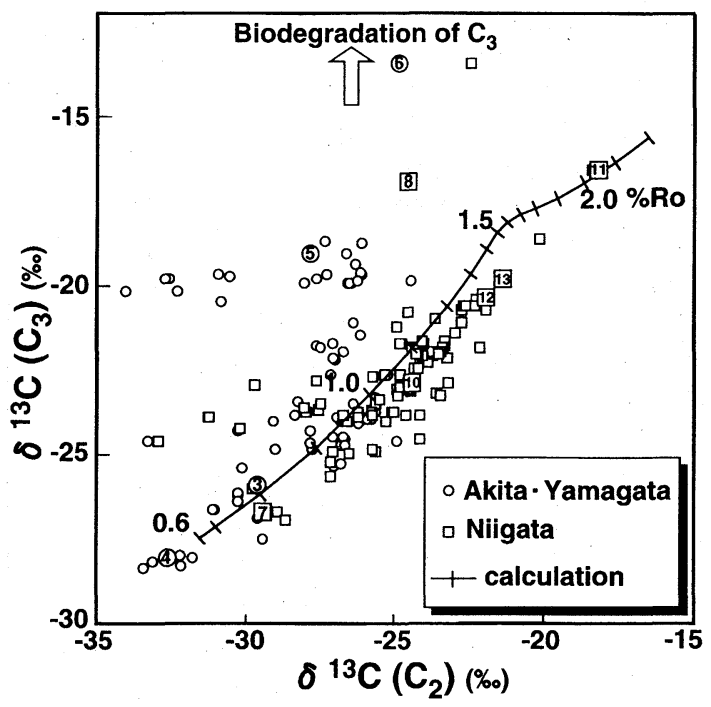

Fig. 9 Relationships between propane and ethane carbon isotope compositions of natural gases in Japan. The vitirnite reflectance/isotope composition line is obtained by calculations using formulas from Berner and Faber (1996), supposing kerogen is Type II and the carbon isotope composition is $-22.3 \%$. Sample numbers refer to Table 1.
域の試料に多い。これらは微生物分解の影響と解釈でき る。これらを除くと，大部分の試料は熟成ラインの近傍 にプロットされるが，ラインよりもややプロパン炭素同 位体組成が軽い側（エタン炭素同位体組成が重い側）に 平行してずれた位置にプロットされている。これは，モ デルがある熟成度に扔ける瞬間的（instantaneous）な ガスの生成を想定しているのに対して，実際には，ある 熟成度範囲で生成したガスの累積であることに起因する と解釈できる (Berner and Faber, 1996)。申川（試料 番号 4 ) の Ro は $0.6 \%$ 以下, 福川（同 3 ), 岩船沖（同 7 ）は $0.8 \%$ 前後, 片貝（同12）は $1.2 \sim 1.3 \%$, 基礎試 錐「三島」(同11) は2\%程度でこの中では最も高い熟成 度が推定される。申川の熟成度が低く推定される原因の 1 つとして, 起源有機物の炭素同位体組成が軽い可能性 がある。実際, 申川油田の原油の芳香族炭化水素組成 は， $-22.6 \%$ 前後でここで仮定した $-22.3 \%$ よりわずか ではあるが軽い（早稲田，1993）。しかし，起源有機物 を一 $22.6 \%$ として再計算した結果む依然として Ro が $0.6 \%$ 以上をなるこから，申川油田のガスの場合，実 際に $0.6 \%$ 以下の低い熟成度で生成した可能性む考えら れる。

以上の推定には，典型的なタイプIケケロジェンを起源 とし，移動時の分別がない，などの仮定が含まれる。さ らに, 起源有機物の炭素同位体組成の推定に不確実性が 含まれる。これらの点は, 今後さらなる検討を要する。 しかし，ある地域のガスの熟成度のおよその目安を得る という点で, このようなモデルによる推定は石油・天然 ガス探鉱に有用であると考える。

モデルによるガスの炭素同位体組成の検討（Fig. 8, 9）からは，上述のように熟成度の推定とと屯にガスの 起源・二次的变質の有無についての情報も得られる。メ タン炭素同位体組成と炭化水素組成によるガスの起源・ 二次的変質の検討（Fig. 1) とモデルによる解釈結果を 総合して, 国内天然ガス13試料についての起源, 二次的 変質 (移動・微生物分解), 熟成度の評価結果を Table 1 に示す。

\section{5. まと め}

メタン・エタン・プロパン炭素同位体組成, メタン水 素同位体組成, 炭化水素組成, ヘリウム同位体比, 根源 ケロジェンのタイプ・炭素同位体組成, などの分析デー 夕から, 炭化水素の起源や熟成度について以下のような 情報が得られることを示した。

(1) 炭素同位体組成とへリウム同位体比から深部起源 のガスの寄与が評価できる。油・ガス田の天然ガス の分析デー夕は, 炭化水素には非生物起源ガスの寄 
与がほとんどないことを示す。

（2）微生物起源と熱分解起源ガスは炭素同位体組成と 炭化水素組成から判別できる。ただし, 両者の混 合, 移動による分別, 微生物分解による分別など, さまざまな要因の影響が考えられるため, 注意が必 要である。特に微生物分解による同位体組成, 炭化 水素組成の変化は大きく, その変化方向も一定して いないため，地質状況も含めた総合的な判断が必要 である。

(3) コンデンセートは, 高熟成の根源岩/油からの生 成, 垂直移動時の気液分離, 脱アスファルト化，な ぞ異なる成因で生成する。油・ガス田内での油層と コンデンセート層の上下関係や油とコンデンセート の炭素同位体組成の比較から，これらの成因の判別 が可能である。

(4) 炭化水素の炭素同位体組成は熟成度を反映する。 国内天然ガスに Berner and Faber（1996）による 同位体組成/熟成度モデルを適用してガスの熟成度 を推定した。その結果, 新潟堆積盆の天然ガスは秋 田・山形堆積盆よりあ全体的に高い熟成度で生成し たことが明らかになった。さらに，モデルは，熟成 度の推定とともに微生物分解の影響や微生物起源ガ スと熱分解起源ガスの混合の評価についても有効で あることを示した。

\section{謝 辞}

本稿の公表を許可していただいた, 秋田県, 石油公 団, 三菱ガス化学株式会社, 日本海洋石油資源開発株式 会社, 石油資源開発株式会社に感謝します。石油資源開 発株式会社探鉱本部, 開発本部および技術研究所の探鉱 関係のかたがたには日頃の討論を通じて有益な助言をい ただきました。

\section{文献}

Abrajano, T. A., Sturchio, N. C., Bohlke, J. K., Lyon, G. L., Poreda, R. J. and Stevens, C. M., 1988 : Methanehydrogen gas seeps, Zambales Ophiolite, Philippines : Deep or shallow origin? Chem. Geol, 71, 211 -222 .

Bernard, B. B., 1978 : Light Hydrocarbons in marine sediments. Ph. D. dissertation, Texas $A \& M$ Univ. College Station, TX.

Berner, U. and Faber, E., 1996 : Empirical carbon isotope/maturity relationships for gases from algal kerogens and terrigenous organic matter, based on dry, open-system pyrolysis. Org. Geochem., 24, 947955.

Berner, U., Faber, E., Scheeder, G. and Panten, D., 1995
: Primary cracking of algal and landplant kerogens : kinetic models of isotope variation in methane, ethane and propane. Chem. Geol., 126, 233-245.

Chung, H.M. and Sackett, W.M., 1980 : Carbon isotope effects during the pyrolytic formation of early methane from carbonaceous materials. In Douglas, A. G. and Maxwell, J. R., eds. : Advances in Organic Geochemistry 1979, 705-710.

Chung, H. M., Gormly, J. R. and Squires, R. M., 1988 : Origin of gaseous hydrocarbons in subsurface environments : theoretical considerations of carbon isotope distribution. Chem. Geol., 71, 97-103.

Clayton, C. J., Hay, S. J., Baylis, S. A. and Dipper, B., 1997 : Alteration of natural gas during leakage from a North Sea salt diapir field. Marine Geol., 137, 69-80.

Connan, J., Lacrampe-Couloume, G. and Magot, M., 1997: Anaerobic biodegradation of petroleum in reservoirs: a widespread phenomenon in nature. In $18^{\text {th }}$ International Meeting on Organic Geochemistry, September 1997, Maastricht, Netherlands, 5-6.

Deines, P., 1980 : The isotopic composition of reduced organic carbon. In Fritz, P. and Fontes, J. C., eds. : Handbook of environmental isotope geochemistry, $v$. 1, The terrestrial environment, 329-406.

Des Marais, D. J., Donchin, J. H., Nehring, N. L. and Truesdell, A. H., 1981 : Molecular carbon isotopic evidence for the origin of geothermal hydrocarbons. Nature, 292, 826-828.

Dimitrakopoulos, R. and Muehlenbachs, K., 1987 : Biodegradation of petroleum as a source of ${ }^{13} \mathrm{C}$ enriched carbon dioxide in the formation of carbonate cement. Chem. Geol., 65, 283-291.

Fuex, A. N., 1977 : The use of stable carbon isotopes in hydrocarbon exploration. J. Geochem. Expl., 7, 155-188.

Fuex, A. N., 1980 : Experimental evidence against an appreciable isotopic fractionation of methane during migration. In Douglas, A. G. and Maxwell, J. R., eds. : Advances in Organic Geochemistry 1979, 725-732.

Galimov, E. M., 1975 : Carbon isotopes in oil-gas geology. U.S. Department of Commerce, National Technical Information Service, N 75-27563, 395.

Galimov, E. M., 1988 : Sources and mechanisms of formation of gaseous hydrocarbons in sedimentary rocks. Chem. Geol., 71, 77-95.

Gold, T. and Soter, S., 1980 : The deep-earth-gas hypothesis. Scientific Amer., 242, 154-161.

Gold, T. and Soter, S., 1982 : Abiogenic methane and the origin of petroleum. Energy Exploration \& Exploitation, 1, 89-104.

Hood, A., Gutjahr, C. C. M. and Heacock, R. L., 1975 : 
Organic metamorphism and the generation of petroleum. AAPG Bull., 59, 986-996.

Hunt, J. M., 1995 : Petroleum Geochemistry and Geology 2nd ed. W. H. Freeman and Company, New York.

Igari, S., 1999 : Carbon isotopic ratios of methane, ethane and propane in natural gases from Niigata and Akita in Japan : Factors affecting the parameters. Geochem. J., 33, 127-132.

Igari, S. and Sakata, S., 1988 : Chemical and isotopic compositions of natural gases from the Japanese major oil and gas fields : Origin and compositional change due to migration. Geochem. J., 22, 257-263.

Igari, S. and Sakata, S., 1989 : Origin of natural gas of dissolved-in-water type in Japan inferred from chemical and isotopic compositions: Occurrence of dissolved gas of thermogenic origin. Geochem. J., 23, 139-142.

James, A. T., 1983 : Correlation of natural gas by use of carbon isotopic distribution between hydrocarbon components. AAPG Bull., 67, 1176-1191.

James, A. T. and B. J. Burns, 1984 : Microbial alteration of subsurface natural gas accumulations. AAPG Bull., 68, 957-960.

北 逸郎 - 長谷川英尚 - 滝沢英夫 - 荒屋敷龍一 - 長尾敬 介・上田 晃, 1999 ：天然ガスの起源と生成環境一 $\mathrm{N}_{2} / \mathrm{Ar}$ 比と $\mathrm{He} / \mathrm{Ar}$ 比からのアプローチ一. 石技誌, 64, 438-447.

Lorant, F., Prinzhofer, A., Behar, F. and Huc, A. Y., 1998 : Carbon isotopic and molecular constraints on the formation and the expulsion of thermogenic hydrocarbon gases. Chem. Geol., 147, 249-264.

Matsumoto, R., Uchida, T., Waseda, A., Uchida, T., Takeya, S., Hirano, T., Yamada, K., Maeda, Y. and Okui, T., 2000 : Occurrence, structure and composition of natural gas hydrate recovered from the Blake Ridge, ODP Leg 164, Northwest Atlantic. In Paull, C. K., Matsumoto, R. and Wallace, P. J. and Dillon, W. P., eds. : Proc. ODP, Sci. Results, 164, College Station, TX (Ocean Drilling Program), 13-28.

Mattavelli, L., Ricchiuto, T. and Martinenghi, C., 1992 : Deep isotopic light methane in northern Italy. In Vially, R., ed. : Bacterial Gas, 121-132, Technip, Paris.

McCarty, H. B. and Felbeck, G. T. Jr., 1986 : High temperature simulation of petroleum formation-IV. Stable carbon isotope studies of gaseous hydrocarbons. Org. Geochem., 9, 183-192.

Oremland, R. S., Whiticar, M. J., Strohmaier, F. E. and Kiene, R. P., 1988 : Bacterial ethane formation from reduced, ethylated sulfur compounds in anoxic sediments. Geochim. Cosmochim. Acta, 52, 18951904.

Pallasser, R. J., 2000 : Recognising biodegradation in gas/oil accumulations through the $\delta^{13} \mathrm{C}$ compositions of gas components. Org. Geochem., 31, 13631373.

Prinzhofer, A. and Pernaton, E., 1997 : Isotopically light methane in natural gas : bacterial imprint or diffusive fractionation? Chem. Geol., 142, 193-200.

Prinzhofer, A., Mello, M. R. and Takaki, T., 2000 : Geochemical characterization of natural gas : a physical multivariable approach and its applications in maturity and migration estimates. $A A P G$ Bull., 84, 1152-1172.

Rogers, M. A., McAlary, J. D. and Bailey, N. J. L., 1974 : Significance of reservoir bitumens to thermalmaturation studies, Western Canada Basin. AAPG Bull., 58, 1806-1824.

Rohrback, B. G., Peters, K. E. and Kaplan, I. R., 1984 : Geochemistry of artificially heated humic and sapropelic sediments- $\Pi$ : oil and gas generation. AAPG Bull., 68, 961-970.

Roony, M. A., Claypool, G. E. and Chung, H. M., 1995 : Modeling thermogenic gas generation using carbon isotope ratios of natural gas hydrocarbons. Chem. Geol., 126, 219-232.

Sakata, S., 1991 : Carbon isotope geochemistry of natural gases from the Green Tuff Basin, Japan. Geochim. Cosmochim. Acta, 55, 1395-1405.

坂田 将・高橋 誠・星野一男, 1986 : 深部火山岩中の 天然ガスの成因に関する地球化学的考察. 石技誌, 51, 228-237.

Sakata, S., Suzuki, N. and Kaneko, N., 1988 : A biomarker study of petroleum from the Neogene Tertiary sedimentary basins in Northeast Japan. Geochem. J., 22, 89-105.

Sakata, S., Takahashi, M., Igari, S. and Suzuki, N., 1989 : Origin of light hydrocarbons from volcanic rocks in the "Green Tuff" region of Northeast Japan : Biogenic versus magmatic. Chem. Geol., 74, 241-248. Sassen, R., MacDonald, I. R., Guinasso, N. L., Jr., Joye, S., Requejo, A. G., Sweet, S. T., Alcala-Herrera, J., DeFreitas, D. A. and Schink, D. R., 1998 : Bacterial methane oxidation in sea-floor gas hydrate: Significance to life in extreme environments. Geology, 26, 851-854.

Schoell, M., 1983 : Genetic characterization of natural gases. AAPG Bull., 67, 2225-2238.

Schoell, M., 1988 : Multiple origins of methane in the earth. Chem. Geol., 71, 1-10.

Scott, A. R., Kaiser, W. R. and Ayers, W. B., Jr., 1994 : Thermogenic and secondary biogenic gases, San Juan Basin, Colorado and New Mexico -implications for coalbed gas producibility. $A A P G$ Bull., 78, 1186-1209.

Silverman, S. R., 1965 : Migration and segregation of oil and gas. In Young, A. and Galley, J. E., eds. : 
Fluids in subsurface environment, AAPG Mem. 4, 53 -65 .

Stahl, W. J., 1979 : Carbon isotopes in petroleum geochemistry. In Jaeger, E. and Hunziker, J. C., eds. : Lectures in Isotope Geology, 274-282.

Sundberg, K. R. and Bennett, C. R., 1983 : Carbon isotope paleothermometry of natural gas. In Bjøroy M. et al., eds. : Advances in Organic Geochemistry 1981, 769-774.

Tang, Y., Perry, J. K., Jenden, P. D. and Schoell, M., 2000 : Mathematical modeling of stable carbon isotope ratios in natural gases. Geochim. Cosmochim. Acta, 64, 2673-2687.

Thompson, K. F. M., 1987 : Fractionated aromatic petroleums and the generation of gas-condensates. Org. Geochem., 11, 573-590.

Uchida, T., Matsumoto, R., Waseda, A., Okui, T., Yamada, K., Uchida, T., Okada, S. and Takano, O., 1999 : Summary of physicochemical properties of natural gas hydrate and associated gas-hydratebearing sediments, JAPEX/JNOC/GSC Mallik 2L38 gas hydrate research well, by the Japanese research consortium. In Dallimore, S. R., Uchida, T. and Collett, T.S., eds. : Scientific Results from JAPEX/JNOC/GSC Mallik 2L-38 Gas Hydrate Research Well, Mackenzie Delta, Northwest Territories, Canada. Geological Survey of Canada Bulletin, 544, 205-228.

Wakita, H. and Sano, Y., $1983:{ }^{3} \mathrm{He} /{ }^{4} \mathrm{He}$ ratios in $\mathrm{CH}_{4}$-rich natural gases suggest magmatic origin. Nature, 305, 792-794.

Wakita, H., Sano, Y., Urabe, A. and Nakamura, Y., 1990 : Origin of methane-rich natural gas in Japan : formation of gas fields due to large-scale subma- rine volcanism. Applied Geochemistry, 5, 263-278.

早稲田 周, 1992 : 本邦原油の炭素・水素同位体組成. Researches in Org. Geochem., 8, 29-33.

早稲田 周, 1993 : 東北日本原油の炭素・水素同位体組 成と熟成度. 石技誌， 58, 199-208.

早稲田 周・重川 守, 1988 : 本邦油・ガス田地帯にお ける天然ガスの起源に関する地球化学的考察. 石技 誌, 53, 213-222.

Waseda, A. and Didyk, B. M., 1995 : Isotope compositions of gases in sediments from the Chile continental margin. In Lewis, S. D., Behrmann, J.H., Musgrave, R. J., and Cande, S. C., eds. : Proc. ODP, Sci. Results, 141, 307-312.

早稲田 周・内田 隆, 1998 : 天然ガスハイドレートの 生成・集積モデル。地質調查所月報, 49, 527-539.

Welhan, J. A. and Craig, H., 1983 : Methane, hydrogen, and helium in hydrothermal fluids at $21^{\circ} \mathrm{N}$ on the East Pacific Rise. In Rona, P. A. et al., eds. : Hydrothermal Processes at Seafloor Spreading Centers, 391-409, Plenum Press.

Whiticar, M. J. and Faber, E., 1986 : Methane oxidation in sediment and water column environments -Isotope evidence. Org. Geochem., 10, 759-768.

Whiticar, M. J., Faber, E. and Schoell, M., 1986 : Biogenic methane formation in marine and freshwater environments : $\mathrm{CO}_{2}$ reduction vs. acetate fermentation-Isotope evidence. Geochim. Cosmochim. Acta, 50, 693-709.

Yuen, G., Blair, N., Des Marais, D. J. and Chang, S., 1984 : Carbon isotope composition of low molecular weight hydrocarbons and monocarboxylic acids from Murchison meteorite. Nature, 307, 252254. 